\title{
Pengukuran Indeks Kebersamaan Masyarakat Dalam Menghadapi Pandemi Covid-19
}

\author{
Didik Setiyadi ${ }^{1,}$, , Syahbaniar Rofiah ${ }^{1}$, Jadi Suriadi ${ }^{2}$ \\ ${ }^{1}$ Fakultas Informatika; Universitas Bina Insani; Jl. Siliwangi No.6 Rawa Panjang Bekasi Bekasi \\ Timur 17114 Indonesia; Telp. (021) 82436886 / (021) 82436 996. Fax. (021) 824009 24; \\ e-mail: didiksetiyadi@binainsani.ac.id; rsyahbaniar@gmail.com \\ ${ }^{2}$ Wellbeing Institute; Ruko Taman Ayodhya No. C 23, Cikokol Tangerang Telp. 081381817146 ; \\ e-mail: wm@wellbeinginstitute.id \\ * Korespondensi: e-mail: didiksetiyadi@binainsani.ac.id
}

\begin{abstract}
At this time the community is being positioned with the corona virus which is not possible for activities outside the home. The role of the community is very important in these conditions, previously the community could move freely outside the house while now it can only stay at home. This study aims to determine the community togetherness index in Covid-19 by using the Wellbeing Methodology (WM) method by measuring through electronic questionnaire (EQ) with 421 respondents from 3 (three) categories namely Jakarta, Bodetabek and outside Jabodetabek. The overall assessment results show a value of 7.23 which means "good" or above the limit of significance. The variable "stay at home" is very well understood by respondents (8.08), but the acceptability of respondents is not good (6.69). Variables "economic aspects", the assessment of community participation and acceptability are not good (6.95) and (6.63).
\end{abstract}

Keywords: Covid 19, Community, Pandemic, Research, Wellbeing.

\begin{abstract}
Abstrak
Pada saat ini masyarakat tengah diposisikan dengan virus corona yang tidak memungkinkan untuk aktivitas diluar rumah. Peran masyarakat sangat penting dalam kondisi seperti ini, sebelumnya masyarakat dapat beraktivitas dengan leluasa diluar rumah sedangkan sekarang hanya dapat berdiam dirumah saja. Penelitian ini bertujuan untuk mengetahui indeks kebersamaan masyarakat pada Covid-19 dengan menggunakan metode Wellbeing Methodology (WM) dengan pengukuran melalui elektronic quisioner (EQ) dengan 421 responden dari 3 (tiga) kategori yaitu Jakarta, Bodetabek dan luar Jabodetabek. Hasil penilaian secara keseluruhan menunjukan nilai 7,23 yang berarti "baik" atau diatas batas angka signifikans. Varibel "tinggal dirumah" dipahami responden dengan sangat baik $(8,08)$, akan tetapi akseptabilitas responden tidak baik $(6,69)$. Variabel "aspek ekonomi", penilaian partisipasi dan akseptabilitas masyarakat tidak baik $(6,95)$ dan $(6,63)$.
\end{abstract}

Kata Kunci: Covid-19, Masyarakat, Pandemi, Riset, Wellbeing.

\section{Pendahuluan}

Pada saat ini masyarakat tengah diposisikan dengan virus corona yang tidak memungkinkan untuk aktivitas diluar rumah. Peran masyarakat sangat penting dalam kondisi seperti ini, sebelumnya masyarakat dapat beraktivitas dengan leluasa diluar rumah sedangkan sekarang hanya dapat berdiam dirumah saja. Menularnya Covid-19 membuat dunia menjadi resah, termasuk di Indonesia (Telaumbanua, 2020). Terhitung sejak awal Januari 2020, dunia mengalami pandemi hebat yang disebut Corona Virus Diseases 2019 (COVID-19) (Albana, 
Submitted: 8 Juni 2020; Revised: 29 Juni 2020; Accepted: 20 Juli 2020; Published: 31 Juli 2020

2020). Pada konteks sekarang, kesadaran sebagai bagian dari masyarakat yang saling mendukung, kesadaran sebagai warga negara sangat dibutuhkan sebagai rasa sadar yang muncul dari hati dan pikiran masyarakat untuk bersikap dan melakukan sebuah tindakan (Arditama \& Lestari, 2020).

Berasal dari keluarga besar virus, virus corona dapat menyebabkan penyakit pernapasan. Sementara gejalanya berkisar dari yang ringan sampai yang sedang, kebanyakan orang terinfeksi virus ini seumur hidup, tetapi dalam kasus yang parah, virus diketahui menjadi alasan dibaliknya pneumonia dan bronkitis, penyakit saluran pernapasan bawah (Amin et al., 2020).

Pandemi adalah bagian dari sejarah. Sebelum Masehi (430 BC), pandemic demam tipoid terjadi di Yunani menewaskan dua pertiga dari populasi. Tahun 2020 menjadi tahunnya infeksi virus Corona diseluruh dunia dimana 215 negara sudah terpapar dengan infeksi virus khususnya SAR-CoV2 ini (Burhanuddin et al., 2020). Coronavirus Diseases 2019 (COVID- 19) adalah penyakit jenis baru yang belum pernah diidentifikasi sebelumnya pada manusia (Dewi, 2020). Coronavirus adalah sekumpulan virus dari subfamili Orthocronavirinae dalam keluarga Coronaviridae dan ordo Nidovirales (Yunus \& Rezki, 2020).

Kriteria sebuah penyakit disebut pandemic virus Corona, yang pertama virus bisa memunculkan penyakit maupun kematian dalam data bisa kita lihat kematian dengan jumlah signifikan dari waktu kewaktu, seperti jumlah Covid-19 diseluruh dunia mencapai angka 2 juta orang, yang kedua penularan virus dari orang keorang terjadi secara pesat, yang ketiga virus telah menyebar hampir ke seluruh pelosok dunia terdapat beberapa penyakit pandemi yang sangat mematikan dalam 24 jam terakhir dari 210 negeri yang memberi tahu terpapar virus Corona terdapat akumulasi 79.936 permasalahan baru (Masrul et al., 2020).

Meskipun banyak faktor yang mempengaruhi perilaku yang berhubungan dengan kesehatan, kesadaran akan risiko untuk membuat perubahan perilaku masyarakat adalah unsur utama untuk meningkatkan kesehatan individu dan status kesehatan masyarakat agar terhindar dari COVID-19 (Sampurno et al., 2020). Penyebaran virus corona ini pada awalnya sangat berdampak pada dunia ekonomi yang mulai lesu (Dewi, 2020). "Social distancing is recommended for all ages to slow the spread of the virus, protect the health care system, and help protect vulnerable older adults" yang diartikan dalam bahasa Indonesia Jarak sosial direkomendasikan untuk semua umur untuk memperlambat penyebaran virus, melindungi sistem perawatan kesehatan, dan membantu melindungi orang dewasa yang rentan (Morbidity and Mortality Weekly Report, 2020).

Penelitian riset publik secara online indeks kebersamaan masyarakat dalam menghadapi pandemi covid-19 (IKM Covid-19). Saat itu penyebaran covid-19 merebak di Indonesia, dengan catatan kurang dipatuhinya anjuran pemerintah "stay at home" dan jaga jarak. Disisi lain, Covid-19 adalah genum virus baru, yang belum pernah ada sebelumnya, konsekuensi logisnya tidak ada vaksin, test memerlukan waktu lama, preparat atau bahan untuk 
testing masih belum merupakan barang produksi masal. Tak ada seorang ahlipun yang tahu segalanya tentang covid-19.

Mengacu pada negara lain, solusi atas masalah pandemi covid-19 telah diketemukan dan didefinisikan dengn jelas yaitu jargon "Jangan tertular dan jangan menularkan". Artinya pemahaman masyarakat, partisipasi masyarakat dan akseptabilitas masyarakat menjadi indikator yang sangat penting. Dalam hal ini konteks dan konten masalah IKM Covid-19, dijabarkan menjadi variabel:
a. Anjuran Pemerintah Tinggal Dirumah Saja
b. Aspek Kesehatan
c. Aspek Ekonomi

Ke tiga aspek tersebut merupakan variabel pengukuran IKM Covid-19, kemudian responden di sebar dalam 3 kategori yang pertama Jakarta, Bodetabek dan luar Jabodetabek.

Dalam mengatasi wabah COVID-19, pemerintah tidak melakukan karantina wilayah (lock down) tetapi menggunakan kebijakan Pembatasan Sosial Berskala Besar (PSBB). Dimulai dari ibukota Jakarta, kebijakan ini diikuti oleh wilayah lainnya. Kota Bekasi sebagai wilayah penyangga Jakarta segera menerapkan kebijakan PSBB mengingat wilayah ini berdekatan dengan dikhawatirkan terpengaruh dengan kota Jakarta yang merupakan zona merah dengan hampir separuh kasus COVID-19 ada di wilayah Jakarta. Banyak pihak yang mendukung dan juga kurang setuju dengan PSBB, namun agar perekonomian tetap berjalan dan wabah dapat diatasi, pemerintah tidak mengambil kebijakan karantina wilayah. Untuk mengetahui efektifitas PSBB di kota Bekasi, penelitian ini mencoba menggunakan model SusceptibleInfectedRecoverd (SIR) untuk mengukur laju penyebaran COVID-19. Hasilnya menunjukan adanya laju penurunan kasus terinfeksi dengan beta dan gamma beruturut-turut sebesar 0,071 dan 0,05 dan diprediksi akan berakhir di bulan Juni 2020. (Handayanto \& Herlawati, 2020).

Hal tersebut didukung oleh beberapa riset di seluruh dunia dalam memprediksi puncak sebaran COVID-19 yang beberapa negara sudah masuk dalam masa lonjakan kedua. Untuk wilayah Indonesia beberapa peneliti menggunakan pendekatan soft computing, seperti Support Vector Machine (SVM) regression, dengan beberapa kernel pilihan, antara lain radial basis function, linear and polynomial dengan akurasi yang beragam. Alat bantu dari Google (Google Interactive Notebook) sangat membantu dengan fasilitas kompiler dan servernya (Herlawati, 2020).

\section{Metode Penelitian}

Metode penelitian yang digunakan yaitu Wellbeing Methodology (WM), dimana secara esensi atas objek kajian Indeks Kebersamaan Masyarakat (IKM) Covid-19, dalam konteks dan konten adalah suatu ukuran kemaslahatan atau kebajikan bagi masyarakat. Hasil ukurannya suatu figure numerik tanpa satuan, disebut sebagai "indeks", dalam hal ini adalah IKM (indeks kebersamaan masyarakat). Konteks kajian dalam topik "melawan pandemi Covid-19" dari sudut pandang pengukuran "kebersamaan masyarakat" atau yang sering disebut gotong 
royong. Hasil pengukuran Indeks IKM Covid-19, dalam bentuk data disimpan dan diolah dalam sistem secara online (cloud computing), dan ada beberapa hal yang bisa dijelaskan sebagai berikut: a). Riset publik secara online atas pengukuran IKM Covid-19, dilakukan secara online, menggunakan alat HP android dalam penyampaian dan pengisian kuesioner secara elektronik, sehingga secara umum bisa dikatakan memenuhi kriteria EETAK (efisien, efektif, transparan, akuntabel, kredibel). b). Cara penetapan variabel, secara teori mengikuti kaidah CIPP (contex, input, process, product) dan hasil keluarannya mengikuti kaidah SMART (specific, measurable, attainable, reasonable \& time bond). c). IKM Covid-19 dengan WM akan menghasilkan data yang mudah, cepat, real time. Sangat cocok untuk kajian ilmu sosial yang sangat dinamis. Selaras dengan objek kajian melawan pandemi Covid-19, dengan waktu terbatas (1 atau 1.5 bulan) dan dilakukan berulang kali. d). Riset publik secara online ini, memerlukan kerjasama kolaborasi, dengan banyak tenaga relawan dan pendampingan kepada seluruh masyarakat, yang belum mengerti. Baik dari sudut pandang pengertian konten maupun cara pengunaan alatnya. e). Riset Publik secara onine, secara umum adalah riset dimana Objek-nya masyarakat dan Subjek-nya juga masyarakat, sehingga akan sesuai dengan kaidah "Riset Inklusif". Rakyat menjadi objek dan subjek, rakyat memahami apa yang dilakukan dalam riset. f). Riset Publik, bisa dikemas menjadi kegiatan sosialisasi, edukasi dan kampanye publik, ditengah masyarakat era digital. Sesuai era digital dimana manajemen kajian berbasis publik sudah bergeser ke arah bottom-up daripada top-down.

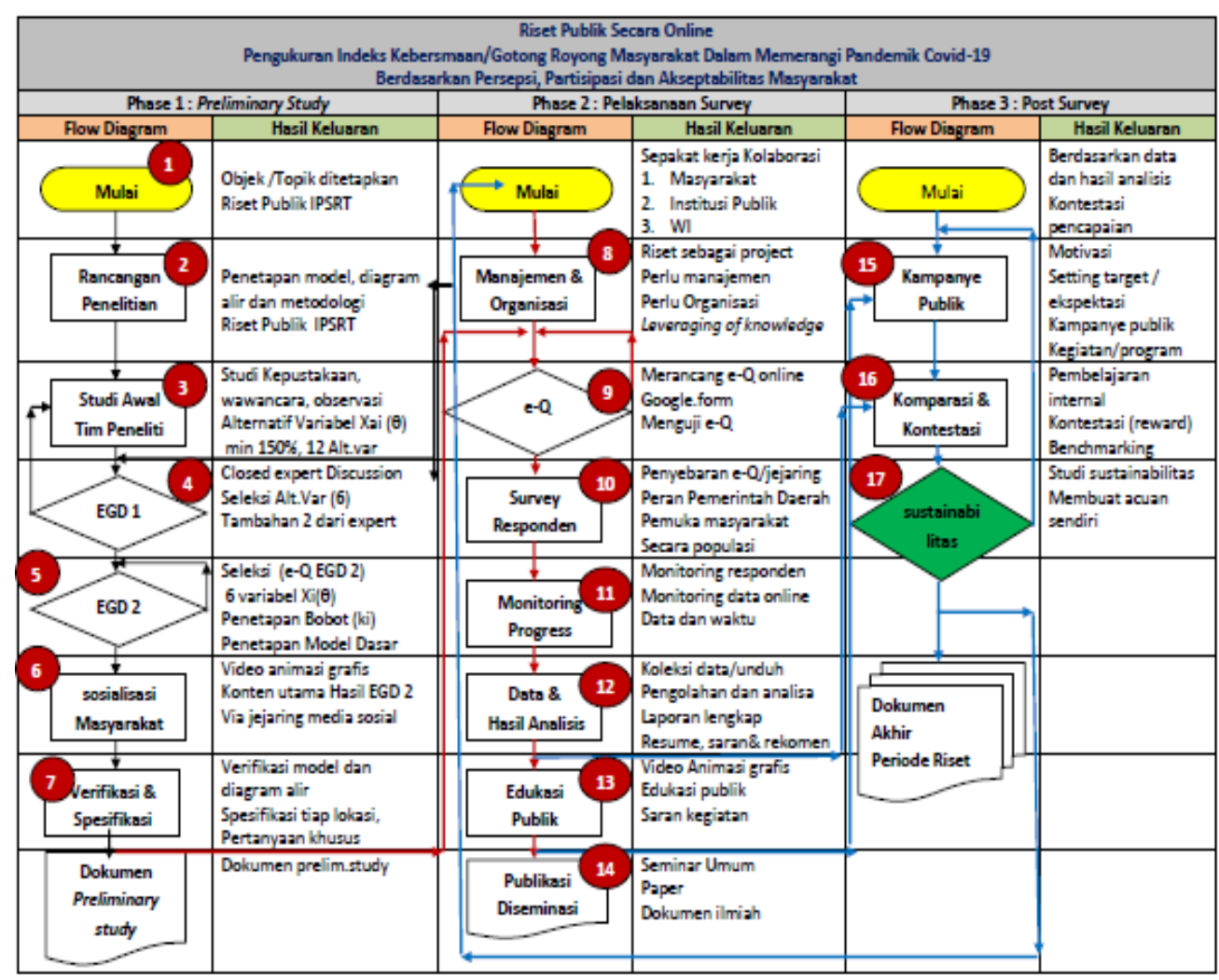

Sumber: Hasil Penelitian (2020)

Gambar 1. Diagram Alir Riset Publik Online 
Gambar 1 merupakan alur kegiatan dari riset publik secara online dibagi menjadi 3 phase dari phase pertama preliminary Study, phase kedua pelaksanaan Survey dan phase ketiga post survey.

\section{Hasil dan Pembahasan}

Penelitian ini dilakukan dalam bentuk riset publik secara online, dimana responden memberikan respon via media sosial (WA, twitter, fB atau e-mail). Instrumen penelitian berupa Persepsi, Partisipasi dan Akseptabilitas (PPA) masyarakat. melakukan interpretasi IKM Covid menjadi 3 variabel penting, yang linier dengan anjuran pemerintah yaitu: 1) Slogan "Tinggal Dirumah Saja", 2) Aspek kesehatan, 3) Aspek ekonomi. Penilaiannya, berupa pengukuran relatif dengan skala likert (9), dengan 3 pertanyaan utama: persepsi, partisipasi dan Akseptabilitas.

Penilaian dilakukan dengan skala likert 9; dengan penjelasan atas nilai sebagai berikut: $1=$ =sangat buruk sekali; 2=sangat buruk; $3=$ =buruk; $4=$ cukup buruk; $5=$ netral/ragu ragu; 6 cukup baik; 7=baik ; $8=$ baik sekali; $9=$ =sangat baik sekali. Pilihan/penetapan titik batas/acuan Signifikansi Penilaian, bisa berdasarkan alternatif, nilai tengah, yaitu skor $=5$, Nilai target tang ditetapkan institusi, nilai rata rata 3 periode sebelumnya dengan mark up (5\%, 10\%, 15\% dan seterusnya). pilihan yang paling rasional adalah menetapkan acuan signifikansi penilaian, "skor 7 (tujuh)" dari tanggal 25 Maret sampai tanggal 30 Maret 2020, didapatkan data responden 421, dan hasil penilaiannya disajikan pada tabel 1.

Tabel 1. Data Skor Penilaian Responden

Data Skor Penilaian Responden (skala Likert 9)

\begin{tabular}{|c|c|c|c|c|}
\hline No & Deskripsi Penilaian & Skor & Signifikansi & Keterangan \\
\hline & Penilaian Persepsi atas Variabel & 8,08 & Signifikan & Sangat baik \\
\hline 1 & "tinggal di rumah saja" & & & \\
\hline 2 & $\begin{array}{l}\text { Penilaian Partisipasi atas Variabel } \\
\text { "tinggal di rumah saja" }\end{array}$ & 7,77 & Signifikan & Baik \\
\hline 3 & $\begin{array}{l}\text { Penilaian Akseptabilitas atas Variabel } \\
\text { "tinggal di rumah saja" }\end{array}$ & 6,69 & Xtidak Signf & Tidak baik \\
\hline 4 & $\begin{array}{l}\text { Penilaian Variabel "tinggal di rumah } \\
\text { saja" secara keseluruhan }\end{array}$ & 7,39 & Signifikan & Baik \\
\hline 5 & $\begin{array}{l}\text { Penilaian Persepsi atas Variabel "aspek } \\
\text { kesehatan" }\end{array}$ & 7,81 & Signifikan & Baik \\
\hline 6 & $\begin{array}{l}\text { Penilaian Partisipasi atas Variabel } \\
\text { "aspek kesehatan" }\end{array}$ & 7,62 & Signifikan & Baik \\
\hline 7 & $\begin{array}{l}\text { Penilaian Akseptabilitas atas Variabel } \\
\text { "aspek kesehatan" }\end{array}$ & 7,00 & Signifikan & Baik \\
\hline
\end{tabular}


Submitted: 8 Juni 2020; Revised: 29 Juni 2020; Accepted: 20 Juli 2020; Published: 31 Juli 2020

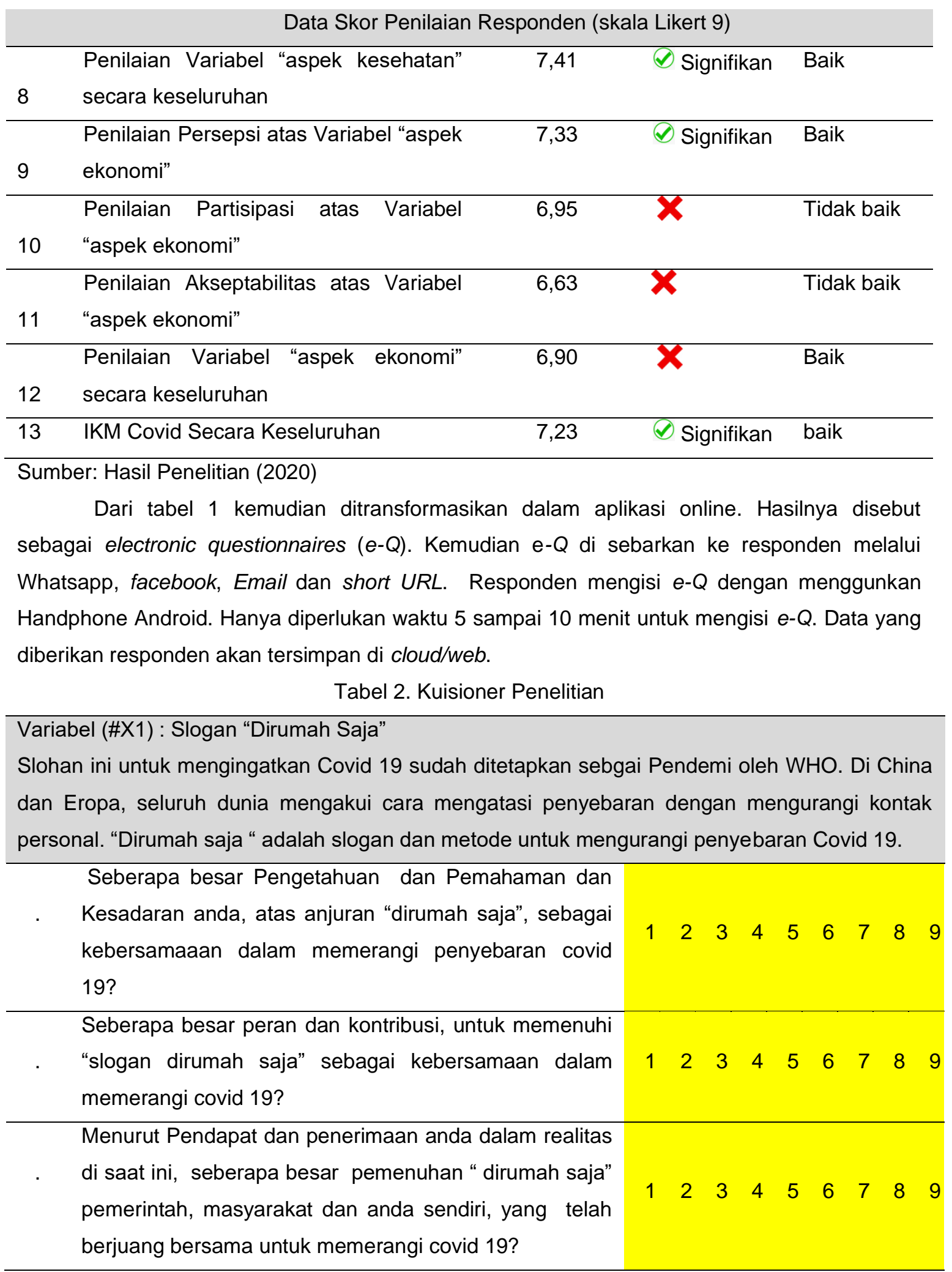


Variabel (\#X2): "Aspek kesehatan", yang dimaksdu aspek kesehata tekait covid 19 ini meliputi:

1. Wabah ini penyebarannya sangat cepat, grafiknya akan berbentuk eksponential

2. Tidak ada satu negarapun yang siap dan atu melakukan antisipasi dengan baik sebelumnya.

3. Penyampaian informasi yang terbuka dari media masa, bagai pisau bermata 2 , membatu antisipasi dan kepanikan yang melemahkan daya tahan tubuh. Kita diminta ambil aspek positifnya saja.

4. Setiap orang diharapkan sehat dan menjaga kesehatan, dirumah masing masing

5. Jangan tertular dan jangan menulari

Seberapa besar Pengetahuan dan Pemahaman dan

Kesadaran anda, atas kondisi "aspek kesehatan", sebagai kebersamaaan dalam memerangi penyebaran covid 19?

Seberapa besar peran dan kontribusi, untuk memenuhi

"aspek kesehatan" sebagai kebersamaan dalam $\begin{array}{llllllllll}1 & 2 & 3 & 4 & 5 & 6 & 7 & 8 & 9\end{array}$ memerangi covid 19?

Menurut Pendapat dan penerimaan anda dalam realitas

di saat ini, seberapa besar penilaian anda pada kondisi

"aspek kesehatan" $\quad$ pemerintah, masyarakat dan anda $\quad \begin{array}{llllllllll}1 & 2 & 3 & 4 & 5 & 6 & 7 & 8 & 9\end{array}$ sendiri, yang telah berjuang bersama untuk memerangi covid 19?

Variabel (\#X3) : Aspek Ekonomi, berbagai hal atas aspek ekonomi atas Covid 19 meliputi :

1. Kegiatan ekonomi macet, hilang sumberdaya dan pendapatan dan bahwa resesi level dunia

2. Waktu lama Covid 19 belum ada yang tahu pasti, semua prediksi, asumsi yg belum tentu benar. Konsekuensinya, masyarakat harus berjuang menjalani kehidupan dengan berbagai keterbatasan.

3. Kebutuhan pangan, menjadi prioritas utama. Berjuang untuk kehiduapan sampai habis waktu pandemi

Aspek kehidupan lain sangat terganggu

Seberapa besar Pengetahuan dan Pemahaman dan

Kesadaran anda, atas kondisi "aspek Ekonomi", sebagai kebersamaaan dalam memerangi penyebaran covid 19?

Seberapa besar peran dan kontribusi anda, untuk kondisi " aspek ekonomi" sebagai kebersamaan dalam memerangi covid 19? 
Menurut Pendapat dan penerimaan anda dalam realitas di saat ini, seberapa besar penilaian kondisi "aspek ekonomi" pemerintah, masyarakat dan anda sendiri, yang telah berjuang bersama untuk memerangi covid $\begin{array}{lllllllll}1 & 2 & 3 & 4 & 5 & 6 & 7 & 8 & 9\end{array}$ $19 ?$

Sumber: Hasil Penelitian (2020)

Data Gambar 2 responden hanya dibatasi pada data domisili dan data umur. Pada data domisili, terlihat dalam grafik, responden dari Jakarta $(23,5 \%)$ dari jabodetabek $(58,9 \%)$ dan dari luar jabodetanek adalah sekitar (17,6\%). Demikian juga pada data umur, bagian yang kecil tidak terlihat angkanya, tapi bisa disajikan dalam data tabulasi dibawah.

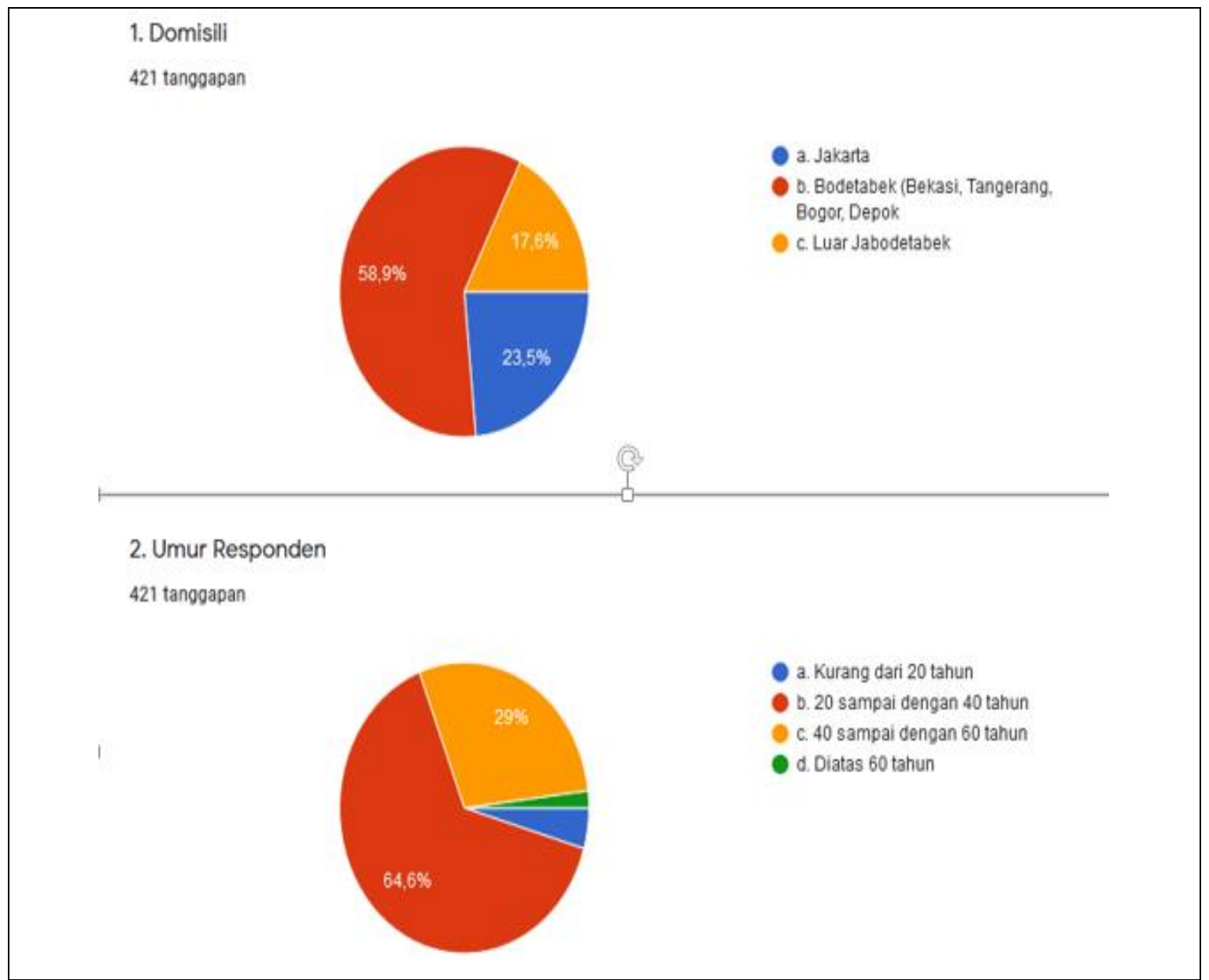

Sumber: Hasil Penelitian (2020)

\section{Gambar 2. Data Responden}

Gambar 3 merupakan hasil penilaian responden dalam bentuk grafik dengan penjelasan sebagai berikut Grafik variabel X1 Poin 1 (Satu): data ini adalah data penilaian Persepsi responden dengan instrumen kuesioner sebagaimana ditampilkan, data publik dengan nilai 8,08 skala Likert (9), termasuk dalam kategori sangat bagus. Hanya ada 6,9\% orang yang menilai dibawah skor 7 atau dibawah standar. Selebihnya 93,1\% menilai dengan skor diatas 7 . Pola umum, grafik adalah "eksponensial" : nilai terbanyak adalah 9 (nilai tertinggi) sangat 
dominan, 41,1\%, menunjukan bahwa masyarakat mengerti betul (tahu, paham dan sadar) atas materi kuesioner variabel "tinggal dirumah saja". Realitas dilapangan memang demikian adanya, 29 orang yang tidak tahu atau memang tidak mau tahu, adalah anomali responden, dalam masyarakat majemuk.

Varlabet ("w X1) s stogan "Oirumah saja"

Seberapa besar Pengetahusn dan Pemahaman dan Kesadaran anda, atas anjuran "dinumeh

saja", sebaga kebersemaan daiem memerangi pemrebaran covid to?

421 twisgonon

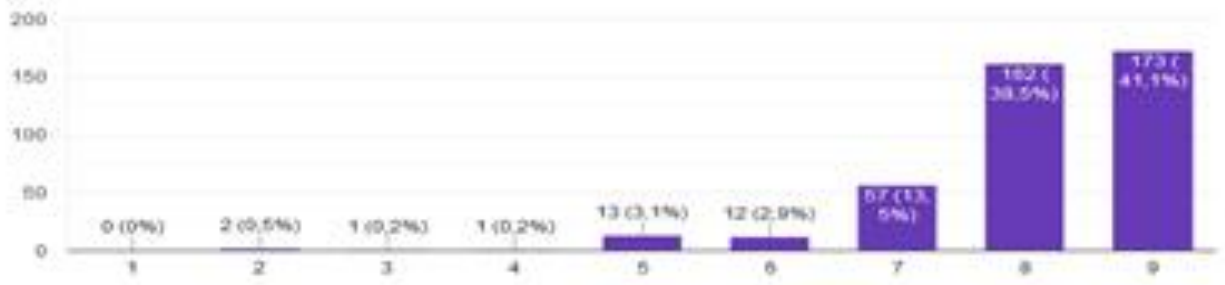

3. Menurut Pendapat dan penerimaan anda dalam realitas di saat inl, seberapa besar pemenuhan " dirumah saja" pemerintah, masyarakat dan anda sendiri, yang telah berjuang bersama untuk memerangi covid 19 ?

420 tangeaban

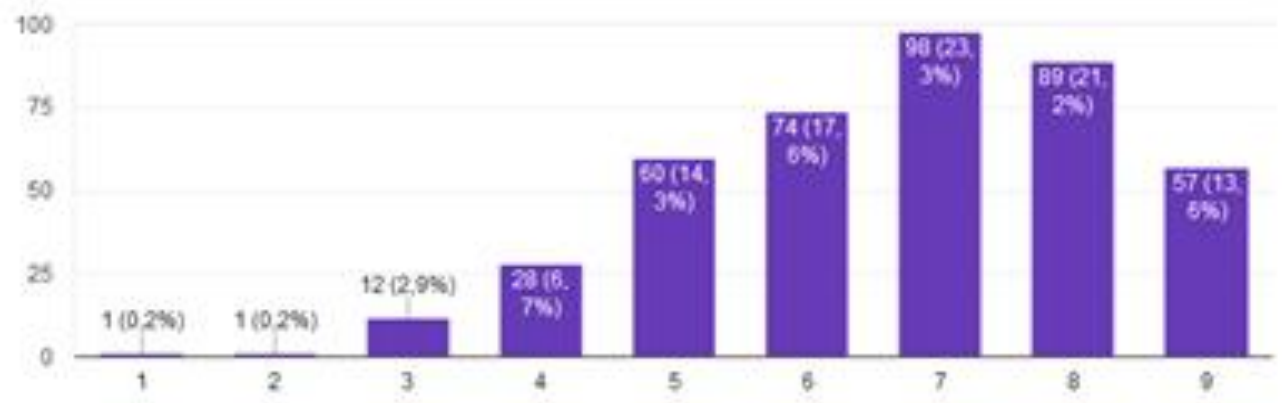

2. Seberapa besar peran dan kontribusl, untuk memenuhl "slogan dirumah saja" sebagal kebersamaan dalam memerangl covid 19 ?

421 unopapas

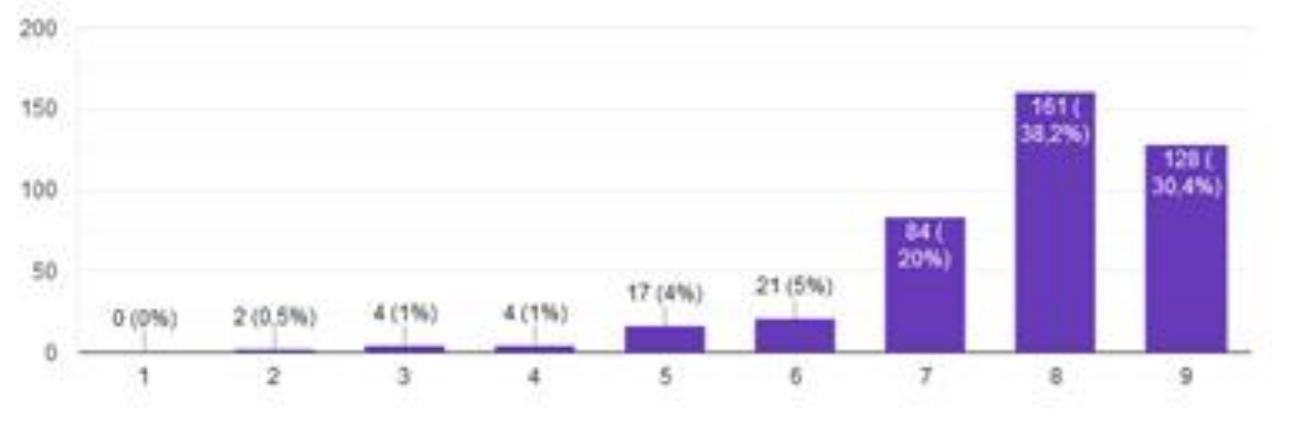

Sumber: Hasil Penelitian (2020)

Gambar 3. Grafik Variabel X1 Slogan Dirumah Saja 
Submitted: 8 Juni 2020; Revised: 29 Juni 2020; Accepted: 20 Juli 2020; Published: 31 Juli 2020

Grafik variabel X1 Poin 2 (dua) Pola grafiknya masih sudah merupakan kurva distribusi normal dengan pergeseran ke kanan. Penilaian Partisipasi ini adalah 7,77. Masuk dalam kategori "baik" dengan batas limit skor 7. Penilaian Partisipasi yang cukup tinggi, konsekuensi logis dari kepentingan personal yang cukup tinggi, juga topik kajian menyangkut masalah bersama yang sangat serius, Walaupun hanya ada 48 orang yang nemilai dibawah skor 7 , semacam dalam kondisi keterpaksaan atau dalam bentuk anomali (orang yang tak peduli). Angkany kecil $11,5 \%$, akan tetapi angka ini menjadi sangat penting untuk diperhatikan, karena dalam hal penyakit Covid-19 (efek domino), walaupun hanya $11,5 \%$ orang yang tak peduli bisa berakibat buruk bagi yang lain. Dalam hal ini, sensitivitas individu menjadi sangat tinggi, sehingga bila ada yang mengabaikan/idak mengikuti anjuran Pemerintah maka akan berpengaruh besar pada yang serius. Kecerobohan 1 orang bisa mengakibatkan masalah pada banyak orang. Dalam realitas dilapangan, fungsi pemerintah tidak cukup kuat atau mampu untuk mengendalikan "anomali" pada posisi masyarakat bawah. Masyarakat atau kita semua harus ikut bertanggung jawab mengendalikan dan mengawasi orang yang termasuk anomali.

Gambar 4 merupakan grafik penilaian responden dari variabel X2 aspek kesehatan pada poin 4 (empat) dari 421 responden mendapatkan hasil 7,39\%, pada poin 5 (lima) 7,81\% dan poin ke 6 (enam) 7,62\% termasuk kategori baik.

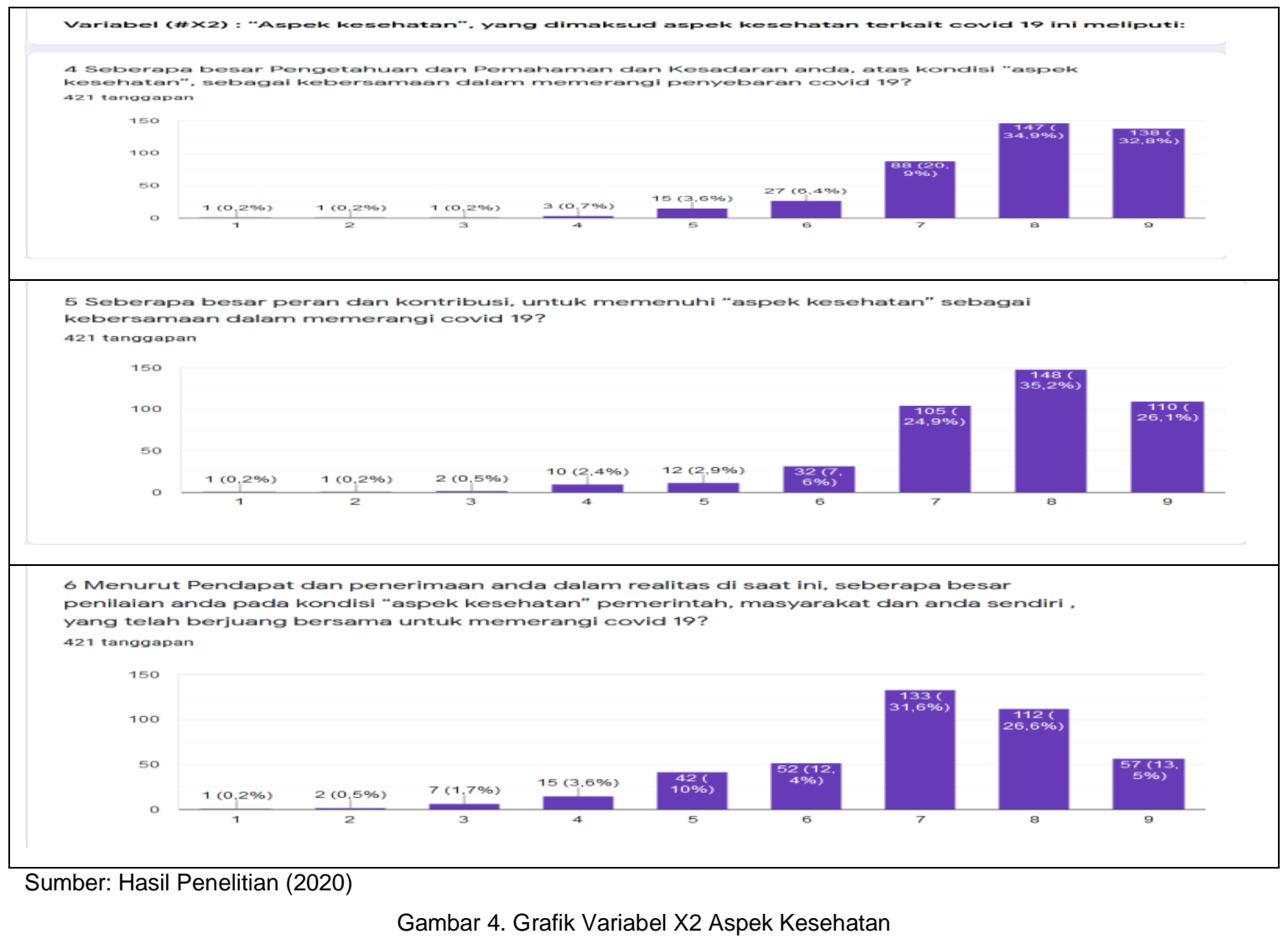

Gambar 5 merupakan grafik penilaian responden dari variabel X3 aspek ekonomi pada poin 7 (tujuh) dari 421 responden mendapatkan hasil 7,00\%, pada poin 8 (delapan) 7,41\% dan poin ke 9 (sembilan) 7,33\% termasuk kategori baik. 


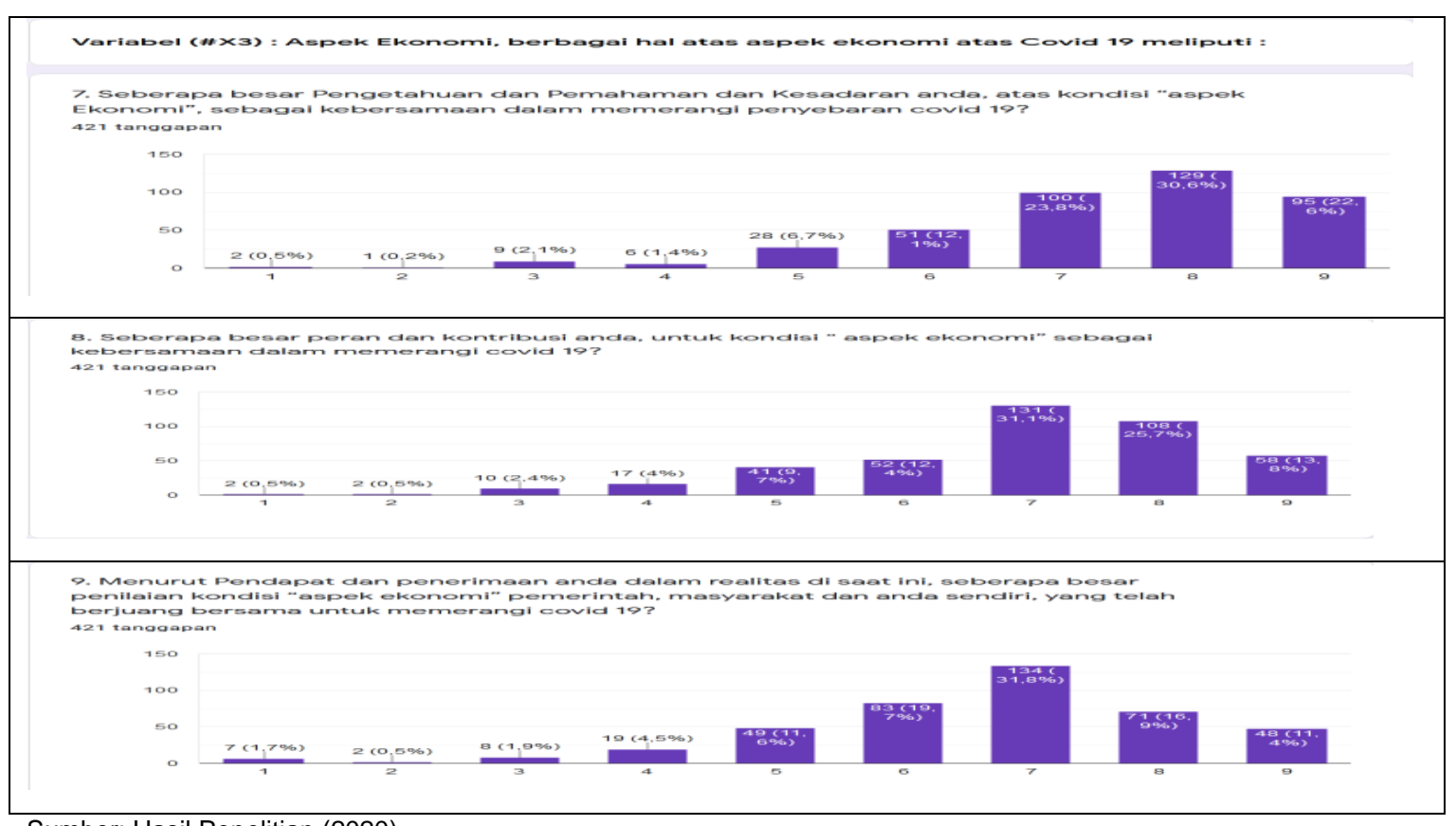

Sumber: Hasil Penelitian (2020)

Gambar 5. Grafik Variabel X3 Aspek Ekonomi

\section{Kesimpulan}

Berdasarkan hasil penelitian dapat disimpulkan Secara kesluruhan hasil penilaian responden atas pertanyaan yang diajukan dalam instrumen pnelitin bisa dijelaskan sebagai berikut:pertama hasil penilaian secara keseluruhan menunjukan nilai 7,23 yang berarti "baik" atau diatas batas angka signifikans. Varibel "tanggal dirumah" dipahami responden dengan sangat baik $(8,08)$, akan tetapi akseptabilitas responden tidak baik $(6,69)$. Variabel "aspek ekonomi", penilaian partisipasi dan akseptabilitas masyarakat tidak baik $(6,95)$ dan $(6,63)$. Kedua perbandingan PPA, dimana nilai terendah adalah nilai akseptabilitas. Hal ini mengindikasikan suatu kondisi realitas yang masih terlalu kecil dibandingkan harapan ekspektasi. Dari segi management impact atas penelitian IKM Covid-19 ini, agar dilakukan riset ini untuk wilayah Kecamatan di seluruh Indonesia, seluruh kelurahan dan desa mendukung, ketua RT/RW menjadi garis depan, mahasiswa dan relawan menjadi tenaga pendamping. Bila riset ini bisa dilakukan setiap minggu sekali, maka diharapkan dalam 4 minggu diharapkan akan ada kesadaran dan kebersamaam masyarakat. Dengan kata lain, penelitian IKM Covid-19 bisa dikemas dalam konteks sosialisasi atas materi (atau program dari pemerintah), dalam konteks edukasi masyarakat bisa dihubungan dengan hasil penilaian (apa yang baik dan apa yang kurang) dan juga kampanye publik, kebersamaan/gotong royong menyelesaikan masalah publik.

\section{Daftar Pustaka}

Albana, A. S. (2020). Optimasi Alokasi Pasien untuk Kasus COVID-19 Wilayah Surabaya. Jurnal Tecnoscienza, 4(2), 181-200.

Amin, M., Saleh, A. M., \& Bilfaqih, H. Z. A. (2020). Covid-19 (Corona Virus Disease 2019): 
Tinjauan Perspektif Keilmuan Biologi, Sosial dan Agama. Inteligensia Media.

Arditama, E., \& Lestari, P. (2020). Jogo Tonggo: Membangkitkan Kesadaran Dan Ketaatan

Warga Berbasis Kearifan Lokal Pada Masa Pandemi Covid-19 Di Jawa Tengah. Jurnal Pendidikan Kewarganegaraan Undiksha, 8(2), 161-166.

Burhanuddin, A. I., Massi, M. N., Marsuki, Thahir, H., Razak, A., \& Surungan, T. (2020). Merajut Asa Di Tengah Pandemi Covid-19 (Pandangan Akademisi UNHAS). Deepublish.

Dewi, W. A. F. (2020). Dampak COVID-19 terhadap Implementasi Pembelajaran Daring di

Sekolah Dasar. Edukatif: Jurnal IImu Pendidikan, 2(1), 55-61. https://doi.org/10.31004/edukatif.v2i1.89

Handayanto, R. T., \& Herlawati, H. (2020). Efektifitas Pembatasan Sosial Berskala Besar (PSBB) di Kota Bekasi Dalam Mengatasi COVID-19 dengan Model Susceptible-InfectedRecovered (SIR). Jurnal Kajian IImiah, 20(2), 119-124. https://doi.org/10.31599/jki.v20i2.119

Herlawati, H. (2020). COVID-19 Spread Pattern Using Support Vector Regression. PIKSEL: Penelitian IImu Komputer Sistem Embedded and Logic, 8(1), 67-74. https://doi.org/10.33558/piksel.v8i1.2024

Masrul, M., Abdillah, L. A., Tasnim, T., Simarmata, J., Daud, D., Sulaiman, O. K., Prianto, C., Iqbal, M., Purnomo, A., Febrianty, F., Saputra, D. H., Purba, D. W., Vinolina, N. S., Napitupulu, D., Soetijono, I. K., Ramadhani, Y. R., Jamaludin, J., Sari, D. C., Mastuti, R., Faried, A. I. (2020). Pandemik COVID-19: Persoalan dan Refleksi di Indonesia. Yayasan Kita Menulis.

Morbidity and Mortality Weekly Report. (2020). Severe Outcomes Among Patients with Coronavirus Disease 2019 (COVID-19) - United States, February 12-March 16, 2020. 2020;69:343-346. DOI: http://dx.doi.org/10.15585/mmwr.mm6912e2. MMWR Morb Mortal Wkly Rep, 69(12), 343-346. https://doi.org/10.15585/mmwr.mm6912e2

Sampurno, M. B. T., Kusumandyoko, T. C., \& Islam, M. A. (2020). Budaya Media Sosial, Edukasi Masyarakat, dan Pandemi COVID-19. SALAM: Jurnal Sosial Dan Budaya Syar-I, 7(5). https://doi.org/10.15408/sjsbs.v7i5.15210

Telaumbanua, D. (2020). Urgensi Pembentukan Aturan Terkait Pencegahan Covid-19 di Indonesia. QALAMUNA: Jurnal Pendidikan, Sosial, Dan Agama, 12(01), 59-70. https://doi.org/10.37680/qalamuna.v12i01.290

Yunus, N. R., \& Rezki, A. (2020). Kebijakan Pemberlakuan Lock Down Sebagai Antisipasi Penyebaran Corona Virus Covid-19. SALAM: Jurnal Sosial Dan Budaya Syar-I, 7(3), 227238. https://doi.org/10.15408/sjsbs.v7i3.15083. 